\title{
KECENDERUNGAN MASALAH GIZI BURUK DI INDONESIA
}

\author{
Abas Basuni Jahari ${ }^{1}$ \\ 1Pusat Penelitian dan Pengembangan Gizi dan Makanan
}

\begin{abstract}
ABSTRAK
Prevalensi gizi kurang dan buruk menurut BB/U belum banyak berubah dari sejak krisis hingga kini, sementara dana untuk program perbaikan gizi semakin meningkat. Revitalisasi Posyandu dan Sistem Kewaspadaan pangan dan Gizi (SKPG) untuk penanggulangan masalah rawan pangan dan gizi di sebagian besar kabupaten di Indonesia tidak diimplementasikan. Telaahan ini bertujuan untuk mempelajari beberapa fakta dari hasil analisis data tentang gizi kurang dan gizi buruk yang terjadi di Indonesia. Data yang digunakan adalah hasil Pemantauan Status Gizi (PSG) Jawa Barat tahun 2004, Hasil Survei Gizi di Provinsi Nanggroe Aceh Darussalam (NAD) pasca-Tsunami, 2005, dan survei masalah gizi mikro di 7 provinsi tahun 2006. Hasil menunjukkan bahwa dari 21,3 persen anak balita yang termasuk kategori rawan, 10 persen di antaranya sangat rawan untuk menjadi status BB/U Rendah (Gizi Kurang). Kemudian, secara umum dari 32,9 persen anak balita berstatus BB/U Rendah yang ada pada posisi rawan, 13,2 persen di antaranya ada pada posisi sangat rawan untuk menjadi status BB/U Sangat Rendah (Gizi Buruk). Berdasarkan TB/U, proporsi anak balita dengan TB/U Normal yang rawan untuk menjadi status TB/U Pendek meningkat seiring dengan bertambahnya umur. Secara umum 39,9 persen anak balita yang berstatus TB/U pendek ada pada posisi rawan, di antaranya 17,8 persen ada pada posisi sangat rawan untuk menjadi status TB/U Sangat Pendek. Namun, berdasarkan BB/TB, hanya 9 persen anak balita berstatus $\mathrm{BB} / \mathrm{TB}$ Normal yang ada dalam posisi rawan, 3,9 persen di antaranya ada pada posisi sangat rawan untuk menjadi status BB/TB Kurus. Karena jumlah anak balita berstatus gizi baik (normal) yang ada pada posisi rawan terus meningkat mengikuti pertambahan usia, maka upaya perbaikan gizi yang bersifat preventif sudah harus dilaksanakan sejak usia dini, tidak hanya untuk anak balita kurang gizi tetapi juga bagi anak balita yang dikategorikan berstatus gizi baik. Arah kebijakan pemerintah hendaknya melalui kegiatan yang bersifat PREVENTIF dan PROMOTIF yang PROAKTIF, harus diimplementasikan secara benar, baik di pusat maupun di daerah.
\end{abstract}

Kata kunci: SKPG, Posyandu, status gizi

THE TREND OF THE OCCURRENCE OF SEVERE UNDERNUTRITION IN INDONESIA

\section{ABSTRACT}

The prevalences of underweight and severely underweight have not been changing since crisis in 1997 up to now, meanwhile the cost for nutrition intervention increase from time to time. Posyandu revitalization and food and nutrition surveillance system (SKPG) to prevent vulnerability in food and nutrition at district level have not been fully implemented. This article is aimed to study several facts resulted from data analysis of undernutrition and severe undernutrition in Indonesia. The data used were taken from nutrition status surveillance system in West Java, 2004; nutrition survey in Nanggroe Aceh Darussalam (NAD) Province after Tsunami, 2005; and micronutruents survey in 7 provinces, 2006. The result showed that among 21.3 percent of children under five years old who categorized as vulnerable, 10 percent were very vulnerable to be underweight using W/A index. In addition, in general, from 32.9 percent of children under five years old who had underweight (W/A) at vulnerable position, 13.2 percent would go down to be severe underweight. Based on $\mathrm{H} / \mathrm{A}$, those who had a normal status would be vulnerable to be stunted as the age increase. Generally, 39.9 percent of children under five who stunted were in the vulnerable position, and 17.8 percent of them were very vulnerable to be severely stunted. However, based on W/H index, among those who were normal, only 9 percent were categorized as vulnerable, and 3.9 percent were in very vulnerable position to be wasted. Because the children who had a normal nutrition status who were vulnerable increased as the age increased, it needs to start the preventive program since early age. The program should be proposed not only for those who had undernutrition but also for children who had a normal nutrition status. The direction of government program should cover preventive, promotive which is procative. The program should be implemented with correct way, either in central or local areas.

Keywords: Food and Nutrition Surveillance System (SKPG), integrated post services, nutritional status 


\section{PENDAHULUAN}

$\mathrm{B}$ eberapa tahun terakhir ini kasus temuan anak di bawah lima tahun (balita) gizi buruk terus menjadi berita, baik di media cetak maupun media elektronik. Upaya penanggulangan anak balita gizi buruk terus ditingkatkan dan disiagakan. Setiap ada laporan tentang anak balita gizi buruk, petugas dinas kesehatan setempat langsung melakukan pengecekan dan konfirmasi di lapangan. Upaya penanggulangan gizi buruk juga dilakukan melalui peningkatan program Manajemen Balita Gizi Buruk untuk melakukan penanganan dan perawatan bagi setiap anak yang menderita gizi buruk. Di samping itu setiap temuan minimal satu kasus anak balita gizi buruk diperlakukan sebagai kejadian luar biasa (KLB). Upayaupaya untuk melakukan deteksi dini gizi buruk sudah disusun oleh Kementerian Kesehatan melalui Sistem Kewaspadaan Dini (SKD) gizi buruk. Perhatian terhadap penanganan kasus gizi buruk sepertinya menjadi prioritas.

Sejak Indonesia mengalami krisis multidimensi tahun 1997, kegiatan-kegiatan revitalisasi Sistem Kewaspadaan Pangan dan Gizi (SKPG) dan revitalisasi Posyandu digalakkan kembali. Pada tahun 1998 dikeluarkan Inpres No. 8, tahun 1998 tentang Gerakan Penanggulangan Masalah Pangan dan Gizi, kemudian disusul dengan Surat Edaran Menteri Dalam Negeri No. 411.3/536/SJ/1999 tentang Revitalisasi Posyandu. Selanjutnya masih pada tahun yang sama Menteri Dalam Negeri (Mendagri) juga mengeluarkan Surat Edaran No. 411.3/1116/SJ/1999 tentang Pedoman Umum Revitalisasi Posyandu.1,2,3 Semua kebijakan, baik yang dituangkan dalam bentuk Inpres, Surat Edaran maupun Surat Keputusan, bertujuan untuk menanggulangi masalah gizi buruk, dengan pengertian bahwa penanggulangan harus bersifat preventif dan promotif selain bersifat rehabilitatif.

Upaya program yang bersifat preventif dan promotif sudah menjadi arah kebijakan program perbaikan gizi masyarakat. ${ }^{4} \mathrm{Di}$ pihak lain, Departemen Pertanian juga melakukan upayaupaya penguatan Sistem Kewaspadaan Pangan dan Gizi (SKPG) untuk penanggulangan masalah rawan pangan dan gizi, dan Departemen Dalam Negeri dengan Revitalisasi Posyandu. Capacity Building di era desentralisasi ini juga sudah dilakukan, baik melalui pelatihan dengan mengundang petugas daerah ke pusat maupun melalui "on-site training", juga sudah dilakukan sosialisasisosialisasi yang semua berkaitan dengan implementasi program perbaikan pangan dan gizi.

Semua upaya perumusan kebijakan, perencanaan dan pelaksanaan program belum membuahkan hasil yang menggembirakan. Kasus rawan pangan dan gizi buruk masih sering ditemukan dan diberitakan. Apa sebenarnya yang terjadi? Apakah ada kesenjangan antara kebijakan dengan perencanaan program, ataukah ada kesenjangan antara perencanaan program dengan implementasinya di lapangan?

Apa yang ditemukan di lapangan ternyata masih jauh dari yang diharapkan. Sebagai contoh, dari 240.000 posyandu hanya 4 persen yang merupakan posyandu mandiri. ${ }^{5}$ Cakupan penimbangan anak balita di posyandu masih rendah, yaitu sekitar 40 persen. ${ }^{6}$ Sama halnya dengan upaya revitalisasi SKPG, hasil yang menggembirakan masih belum tampak. Pada tahun 2005 dilakukan evaluasi pelaksanaan SKPG di 120 kabupaten dan ternyata hampir separuhnya, yaitu sebesar 47,5 persen tidak mengimplementasikan SKPG. ${ }^{7}$ Setahun setelah kesepakatan bupati dan atau walikota tentang implementasi SKPG ternyata masih 46 persen yang tidak mengimplementasikan SKPG. ${ }^{8}$

Perkembangan masalah gizi dari data nasional (Susenas 1999 - 2005) juga belum menggembirakan. Prevalensi gizi kurang (berat badan rendah) dan buruk (berat badan sangat rendah) yang diukur dengan indikator berat badan menurut umur (BB/U) belum banyak berubah, sementara dana untuk program perbaikan gizi semakin meningkat.

Sepertinya masalah-masalah yang dikemukakan di atas berkaitan dengan masih lemahnya implementasi program sebagai pengejawantahan kebijakan pembangunan di bidang pangan dan gizi. Di samping itu kebijakan penanggulangan masalah gizi buruk masih terfokus perhatiannya pada penanganan kasus dan masih kurang dalam upaya pencegahan terjadinya kasus gizi buruk. Selain itu koordinasi antar-berbagai sektor terkait dengan masalah pangan dan gizi dalam mengintegrasikan program-programnya masih belum terlaksana dengan baik. Dalam makalah ini penulis mengemukakan beberapa fakta dari 
hasil analisis data yang ada, dan menggarisbawahi pentingnya memberikan perhatian pada kecenderungan meningkatnya kasus gizi kurang dan buruk sehingga dapat diupayakan pencegahan terjadinya masalah gizi yang lebih besar lagi.

\section{METODE PENELITIAN}

Data yang digunakan penulis untuk analisis tersebut adalah berasal dari:

1. Hasil Pemantauan Status Gizi (PSG) Jawa Barat tahun 2004.

2. Hasil Survei Gizi di Provinsi Nanggroe Aceh Darussalam (NAD) pasca-Tsunami oleh UNICEF, bekerja sama dengan Puslitbang Gizi dan Makanan, tahun 2005.

3. Survei masalah gizi mikro di 7 provinsi (Sumatera Barat, Sumatera Selatan, Banten, Bali, NTB, Kalimantan Selatan dan Sulawesi Tenggara) yang dilakukan oleh Susilowati Herman dkk tahun 2006.

Ketiga survei mengumpulkan data antropometri yang sama, yaitu berat badan dan tinggi badan. Untuk keperluan analisis semua data dari ke tiga survei digabung menjadi satu data set. Dalam analisis dilakukan perhitungan proporsi anak balita yang ada pada posisi rawan untuk jatuh ke keadaan yang lebih buruk. Tiga indikator antropometri digunakan untuk menetapkan posisi rawan, yaitu: ${ }^{9}$

1. Untuk indikator berat badan (BB) menurut umur $(U)$ atau disingkat $\mathrm{BB} / \mathrm{U}$ digunakan 4 kriteria batas rawan, yaitu: (1) Batas Z_Score -1,75 SD ke 2 SD dipakai sebagai posisi sangat rawan untuk jatuh dari $\mathrm{BB} / \mathrm{U}$ Normal (Gizi Baik) ke BB/U Rendah (Gizi kurang); (2) Batas Z_Score -1,75 SD 1,5 SD sebagai posisi cukup rawan untuk jatuh dari BB/U Normal ke BB/U Rendah; (3) Batas Z_Score -2,75 SD ke $-3,0$ SD digunakan sebagai posisi sangat rawan untuk jatuh dari $\mathrm{BB} / \mathrm{U}$ Rendah (gizi kurang) ke BB/U Sangat Rendah (gizi buruk); dan (4) Batas Z_Score $-2,75$ ke $-2,5$ sebagai batas cukup rawan untuk jatuh dari BB/U Rendah (gizi kurang) ke BB/U Sangat Rendah (gizi buruk).

2. Untuk indikator tinggi badan (BB) menurut umur $(U)$ atau disingkat TB/U digunakan 4 kriteria batas rawan, yaitu: (1) Batas Z_Score -1,75 SD ke 2 SD dipakai sebagai posisi sangat rawan untuk jatuh dari TB/U Normal ke TB/U Pendek; (2) Batas ZScore -1,75 SD -1,5 SD sebagai posisi cukup rawan untuk jatuh dari TB/U Normal ke TB/U Pendek; (3) Batas Z_Score -2,75 SD ke -3,0 SD digunakan sebagai posisi sangat rawan untuk jatuh dari TB/U Pendek ke TB/U Sangat Pendek; dan (4) Batas Z_Score -2,75 ke -2,5 sebagai batas cukup rawan untuk jatuh dari TB/U Pendek ke TB/U Sangat Pendek.

3. Untuk indikator tinggi badan (BB) menurut tinggi badan (TB) atau disingkat $\mathrm{BB} / \mathrm{TB}$ digunakan 4 kriteria batas rawan, yaitu: (1) Batas Z_Score $-1,75$ SD ke -2 SD dipakai sebagai posisi sangat rawan untuk jatuh dari BB/TB Normal ke BB/TB Kurus; (2) Batas Z_Score $-1,75$ SD -1,5 SD sebagai posisi cukup rawan untuk jatuh dari BB/TB Normal ke BB/TB Kurus; (3) Batas Z_Score -2,75 SD ke $-3,0$ SD digunakan sebagai posisi sangat rawan untuk jatuh dari $\mathrm{BB} / \mathrm{TB}$ Kurus ke BB/TB Sangat Kurus; dan (4) Batas Z_Score -2,75 ke -2,5 sebagai batas cukup rawan untuk jatuh dari BB/TB Kurus ke BB/TB Sangat Kurus.

Untuk melihat apakah posisi rawan tersebut dialami oleh semua anak balita dari berbagai umur, maka mereka dikelompokkan ke dalam 56 kelompok umur, yaitu: $<6$ bulan (untuk yang tersedia datanya), 6-11 bulan, 12-23 bulan, 2435 bulan, $36-47$ bulan dan $48-60$ bulan.

Data antropometri dianalisis dengan menggunakan Anthro-2005 software yang dikembangkan WHO.10 Interpretasi hasil analisis dilakukan dengan menghitung proporsi anak pada status gizi tertentu yang ada pada posisi rawan.

\section{HASIL}

\section{Proporsi anak dalam posisi rawan berdasarkan indikator BB/U}

Untuk memudahkan pemahaman, semua hasil analisis disajikan dalam bentuk grafik balok (bar chart). Gambar 1 menyajikan proporsi anak balita yang ada pada posisi rawan dan sangat rawan untuk jatuh dari BB/U 
Normal ke BB/U Rendah, dan Gambar 2 posisi rawan dan sangat rawan untuk jatuh dari menyajikan proporsi anak balita yang ada pada BB/U Rendah ke BB/U Sangat Rendah.

Gambar 1. Proporsi Balita BB Normal Menurut Tingkat Kerawanan Menjadi BBRendah (Indikator BB/U)

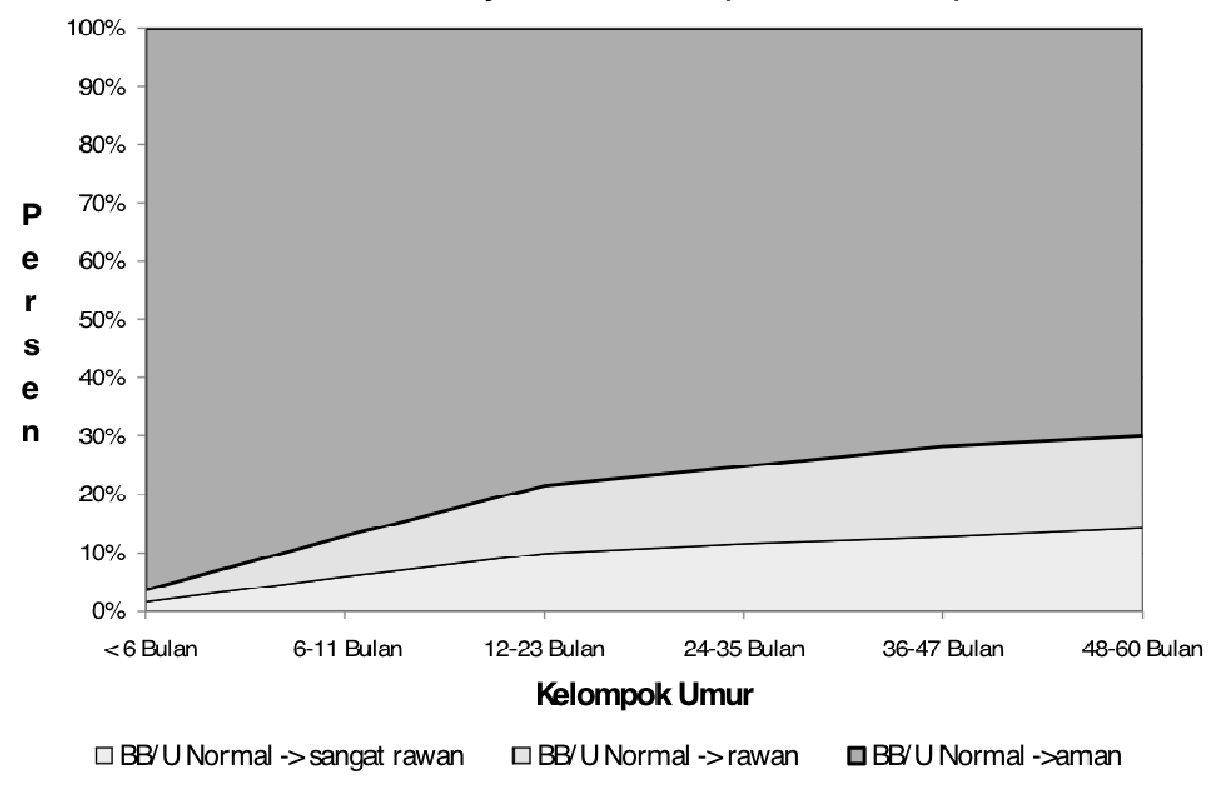

Gambar 2. Proporsi Balita BB Rendah Menurut Tingkat Kerawanan Menjadi BB Sangat Pendah (Indikator BB/U)

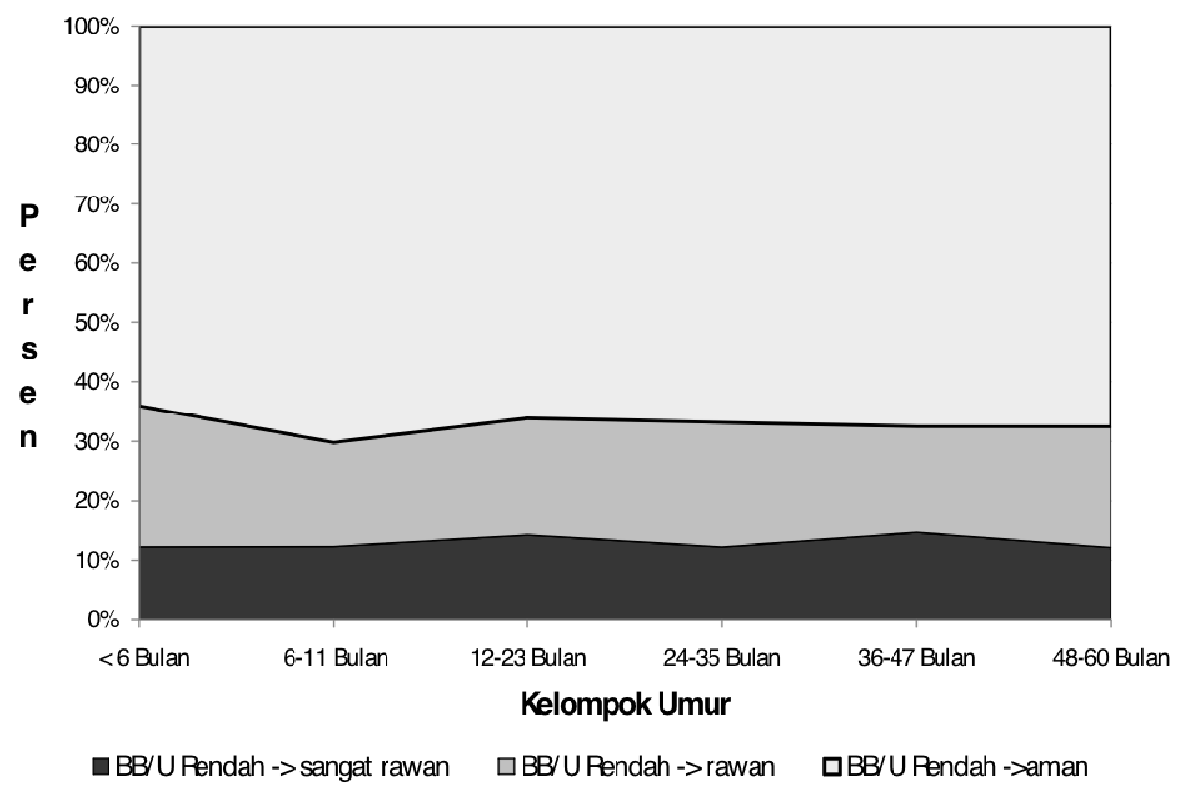

Dari Gambar 1 terlihat bahwa posisi rawan dan sangat rawan untuk jatuh dari BB/U Normal ke BB/U Rendah semakin meningkat seiring bertambahnya umur anak. Tingkat kerawanan terendah pada kelompok umur kurang dari 6 bulan. Dari 21,3 persen anak balita yang termasuk kategori rawan, 10 persen di antaranya (Tabel 1) sangat rawan untuk jatuh ke status BB/U Rendah (Gizi Kurang). 
Tabel 1

Proporsi Anak Balita dengan BB/U Normal yang Memiliki Kerawanan untuk Menjadi BB/U Rendah (Gizi Kurang)

\begin{tabular}{lcccc}
\hline Kelompok Umur & $\begin{array}{c}\text { BB/U Normal } \\
\text { > sangat rawan (A) }\end{array}$ & $\begin{array}{c}\text { BB/U Normal } \\
->\text { rawan (B) }\end{array}$ & Jumlah A+B & $\begin{array}{c}\text { BB/U Normal } \\
->>\text { aman }\end{array}$ \\
\hline <6 Bulan & 1,6 & 2,0 & 3,6 & 96,4 \\
6-11 Bulan & 5,9 & 6,9 & 12,8 & 87,2 \\
12-23 Bulan & 9,9 & 11,6 & 21,5 & 78,5 \\
24-35 Bulan & 11,5 & 13,3 & 24,8 & 75,2 \\
36-47 Bulan & 12,7 & 15,5 & 28,2 & 71,8 \\
48-60 Bulan & 14,2 & 15,8 & 30,0 & 70,0 \\
\hline Jumlah & 9,8 & 11,5 & 21,3 & 78,7 \\
\hline
\end{tabular}

Pada Gambar 2, tingkat kerawanan untuk jatuh dari BB/U Rendah ke BB/U Sangat Rendah terlihat hampir sama di semua kelompok umur. Secara umum ditunjukkan bahwa dari 32,9 persen anak balita berstatus
BB/U Rendah yang ada pada posisi rawan 13,2 persen di antaranya (Tabel 2) ada pada posisi sangat rawan untuk jatuh ke status $\mathrm{BB} / \mathrm{U}$ Sangat Rendah (Gizi Buruk).

Tabel 2

Proporsi Anak Balita dengan BB/U Rendah (Gizi Kurang) yang Memiliki Kerawanan untuk Menjadi BB/U Rendah (Gizi Kurang)

\begin{tabular}{lcccc}
\hline Kelompok Umur & $\begin{array}{c}\text { BB/U Rendah } \\
\text {-> sangat rawan (A) }\end{array}$ & $\begin{array}{c}\text { BB/U Rendah } \\
\text {-> rawan (B) }\end{array}$ & Jumlah A+B & $\begin{array}{c}\text { BB/U Rendah } \\
\text {->aman }\end{array}$ \\
\hline <6 Bulan & 12,2 & 23,8 & 36,0 & 64,0 \\
6-11 Bulan & 12,2 & 17,6 & 29,8 & 70,2 \\
12-23 Bulan & 14,2 & 19,7 & 33,9 & 66,1 \\
24-35 Bulan & 12,1 & 21,0 & 33,2 & 66,8 \\
36-47 Bulan & 14,6 & 17,9 & 32,5 & 67,5 \\
48-60 Bulan & 12,0 & 20,4 & 32,5 & 67,5 \\
\hline Jumlah & 13,2 & 19,7 & 32,9 & 67,1 \\
\hline
\end{tabular}

\section{Proporsi anak dalam posisi rawan berdasarkan indikator TB/U}

Gambar 3 menyajikan proporsi anak balita berstatus TB/U Normal yang memiliki kerawanan jatuh ke status TB/U Pendek. Seperti halnya indikator BB/U, dalam Gambar 3 di atas juga terlihat bahwa proporsi anak balita dengan TB/U Normal yang rawan untuk jatuh ke status TB/U Pendek meningkat seiring dengan bertambahnya umur.

Sebanyak 23,5 persen anak balita ada dalam posisi rawan, 17,8 persen di antaranya dalam posisi sangat rawan untuk jatuh ke status TB/U Pendek (Tabel 3). 


\section{Gambar 3. Proporsi Balita Normal Menurut Tingkat Kerawanan Menjadi Pendek (Indikator TB/U)}

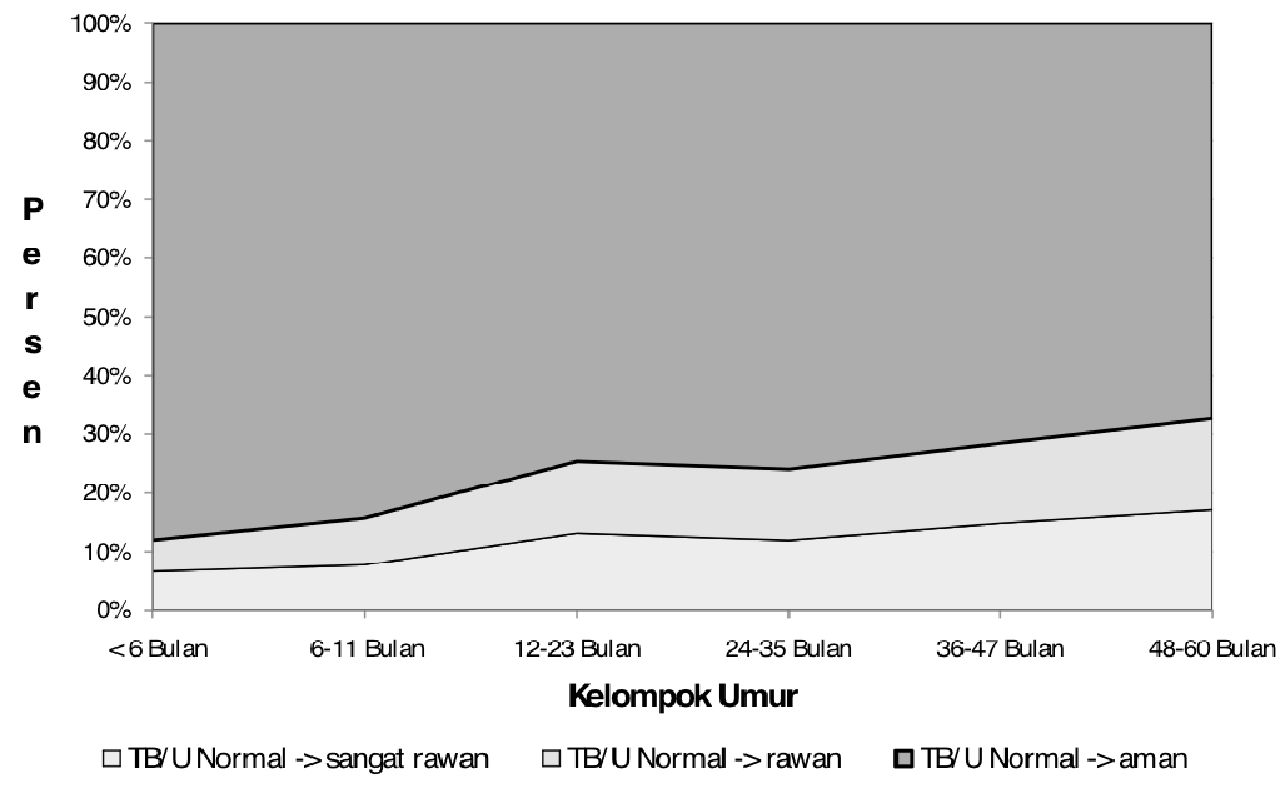

Tabel 3

Proporsi Anak Balita dengan TB/U Normal yang Memiliki Kerawanan untuk Menjadi TB/U Pendek

\begin{tabular}{lcccc}
\hline Kelompok Umur & $\begin{array}{c}\text { TB/U Normal } \\
\text {-> sangat rawan (A) }\end{array}$ & $\begin{array}{c}\text { TB/U Normal } \\
\text {-> rawan (B) }\end{array}$ & Jumlah A+B & $\begin{array}{c}\text { TB/U Normal } \\
\text {-> aman }\end{array}$ \\
\hline < 6 Bulan & 6,6 & 5,3 & 12,0 & 88,0 \\
6-11 Bulan & 7,7 & 8,0 & 15,7 & 84,3 \\
12-23 Bulan & 13,1 & 12,3 & 25,4 & 74,6 \\
24-35 Bulan & 11,9 & 12,1 & 24,1 & 75,9 \\
36-47 Bulan & 14,8 & 13,6 & 28,4 & 71,6 \\
48-60 Bulan & 17,1 & 15,5 & 32,6 & 67,4 \\
\hline Jumlah & 12,1 & 11,4 & 23,5 & 76,5 \\
\hline
\end{tabular}

Gambar 4 di bawah menyajikan informasi tentang proporsi anak balita berstatus TB/U Pendek yang rawan untuk jatuh ke status TB/U Sangat Pendek. Dari gambar ini terlihat bahwa tingkat kerawanan anak balita yang sudah berstatus TB/U Pendek untuk jatuh ke status $\mathrm{TB} / \mathrm{U}$ sangat pendek tidak berbeda banyak antar-kelompok umur. Pada Tabel 4 terlihat bahwa secara umum 39,9 persen anak balita yang berstatus TB/U pendek ada pada posisi rawan, di antaranya 17,8 persen ada pada posisi sangat rawan untuk jatuh ke status TB/U Sangat Pendek. 
Gambar 4. Proporsi Balita Pendek Menurut Tingkat Kerawanan Menjadi Sangat Pendek (Indikator TB/U)

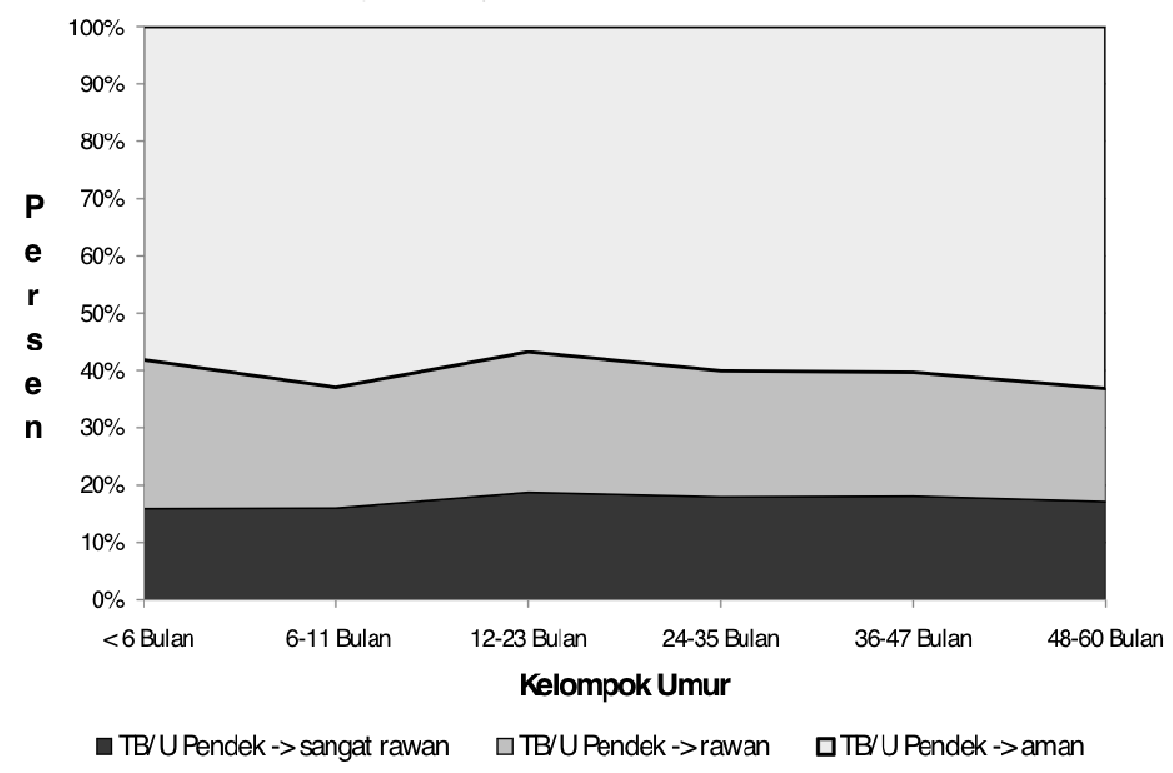

Tabel 4

Proporsi Anak Balita dengan TB/U Pendek yang Memiliki Kerawanan untuk Menjadi TB/U Sangat Pendek

\begin{tabular}{lcccc}
\hline Kelompok Umur & $\begin{array}{c}\text { TB/U Pendek } \\
\text {-> sangat rawan (A) }\end{array}$ & $\begin{array}{c}\text { TB/U Pendek } \\
->\text { rawan (B) }\end{array}$ & Jumlah A+B & $\begin{array}{c}\text { TB/U Pendek } \\
\text {-> aman }\end{array}$ \\
\hline <6 Bulan & 16,0 & 25,9 & 41,8 & 58,2 \\
6-11 Bulan & 16,1 & 21,0 & 37,1 & 62,9 \\
12-23 Bulan & 18,8 & 24,4 & 43,2 & 56,8 \\
24-35 Bulan & 18,0 & 22,0 & 39,9 & 60,1 \\
36-47 Bulan & 18,1 & 21,6 & 39,7 & 60,3 \\
48-60 Bulan & 17,2 & 19,7 & 36,9 & 63,1 \\
\hline Jumlah & 17,8 & 22,1 & 39,9 & 60,1 \\
\hline
\end{tabular}

Proporsi anak dalam posisi rawan berdasarkan indikator $\mathrm{BB} / \mathrm{TB}$

Keadaan serupa juga ditemukan pada anak yang saat ini memiliki BB/TB normal dan kurus.
Gambar 5 dan 6 menyajikan informasi tentang proporsi anak dalam kondisi normal dan kurus yang ada pada posisi rawan untuk menjadi lebih buruk. 
Gambar 5. Proporsi Balita Normal Menurut Tingkat Kerawanan Untuk Menjadi Kurus(Indikator BB/TB)

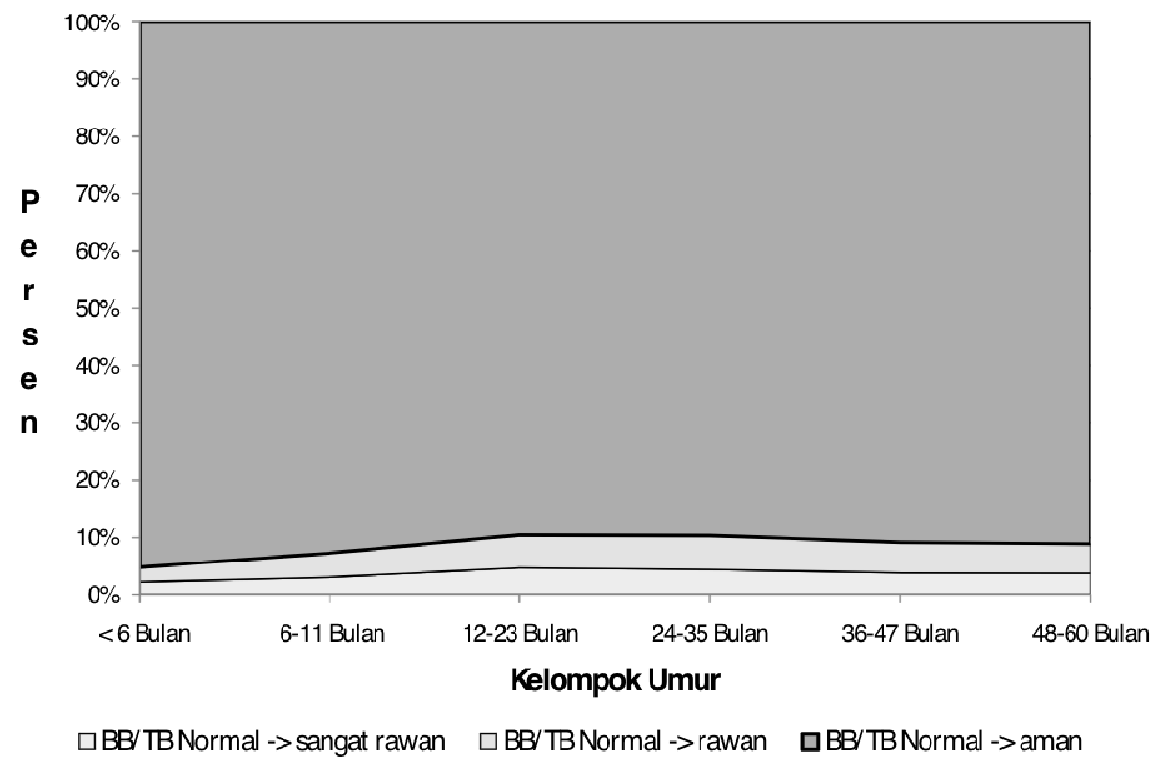

Dalam Gambar 5 dapat dilihat bahwa proporsi anak balita berstatus BB/TB Normal yang ada pada posisi rawan untuk menjadi kurus jauh lebih rendah dari porporsi anak balita Normal yang ada dalam posisi rawan yang dinilai dengan indikator BB/U dan TB/U. Tingkat kerawanan antar-kelompok umur relatif sama, tetapi tetap terendah pada kelompok umur $<6$ bulan.

Pada Tabel 5 terlihat secara umum hanya 9 persen anak balita berstatus BB/TB Normal yang ada dalam posisi rawan, 3,9 persen di antaranya ada pada posisi sangat rawan untuk jatuh ke status BB/TB Kurus.

Tabel 5

Proporsi Anak Balita dengan BB/TB Normal yang Memiliki Kerawanan untuk Menjadi BB/TB Kurus

\begin{tabular}{lcccc}
\hline Kelompok Umur & $\begin{array}{c}\text { BB/TB Normal } \\
\text { > sangat rawan (A) }\end{array}$ & $\begin{array}{c}\text { BB/TB Normal } \\
\text { > rawan (B) }\end{array}$ & Jumlah A+B & $\begin{array}{c}\text { BB/TB Normal } \\
->\text { aman }\end{array}$ \\
\hline <6 Bulan & 2,2 & 2,6 & 4,7 & 95,3 \\
6-11 Bulan & 3,0 & 4,2 & 7,3 & 92,7 \\
12-23 Bulan & 4,7 & 5,8 & 10,5 & 89,5 \\
24-35 Bulan & 4,4 & 6,0 & 10,3 & 89.7 \\
36-47 Bulan & 3,8 & 5,3 & 9,1 & 90,9 \\
48-60 Bulan & 3,7 & 5,1 & 8,9 & 91,1 \\
\hline Jumlah & 3,9 & 5,1 & 9,0 & 91,0 \\
\hline
\end{tabular}

Berbeda dengan tingkat kerawanan yang dimiliki anak balita berstatus BB/TB Normal, pada anak balita berstatus $\mathrm{BB} / \mathrm{TB}$ Kurus, tingkat kerawanan untuk menjadi lebih buruk lebih tinggi. Tingkat kerawanan anak balita berstatus BB/TB Kurus terlihat hampir sama pada semua kelompok umur. 
Gambar 6. Proporsi Balita Kurus Menurut Tingkat Kerawanan Untuk Menjadi Sangat Kurus (Indikator BB/TB)

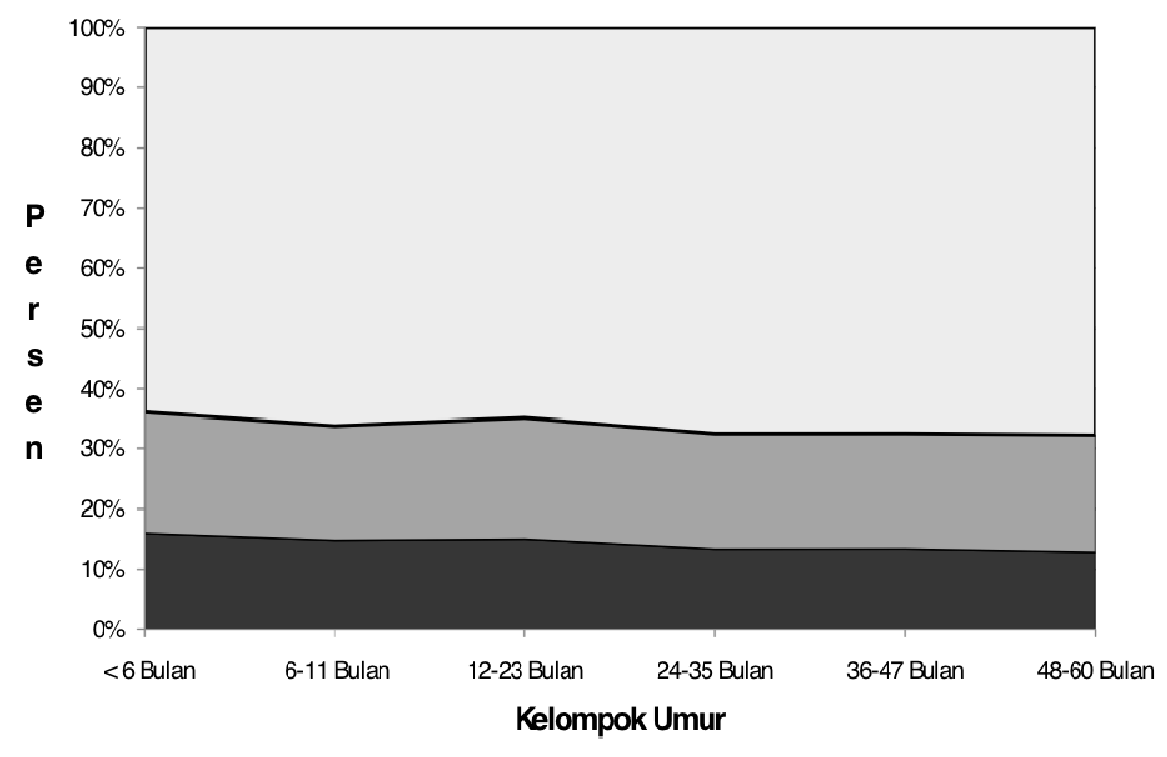

aBB/TBKurus -> sangat rawan $\quad \square B B / T B K u r u s->$ rawan $\quad \square B B / T B K u r u s->$ aman

Dari Tabel 6 dapat dilihat bahwa secara umum terdapat 33,5 persen anak balita berstatus $\mathrm{BB} / \mathrm{TB}$ kurus yang ada pada posisi rawan, 13,9 persen di antaranya ada pada posisi sangat rawan untuk jatuh ke status BB/TB Sangat Kurus.

Tabel 6

Proporsi Anak Balita dengan BB/TB Kurus yang Memiliki Kerawanan untuk Menjadi BB/TB Sangat Kurus

\begin{tabular}{lcccc}
\hline Kelompok Umur & $\begin{array}{c}\text { BB/TB Kurus } \\
\text {-> sangat rawan (A) }\end{array}$ & $\begin{array}{c}\text { BB/TB Kurus } \\
\text {-> rawan (B) }\end{array}$ & Jumlah A+B & $\begin{array}{c}\text { BB/TB Kurus } \\
\text {-> aman }\end{array}$ \\
\hline < 6 Bulan & 15,9 & 20,2 & 36,1 & 63,9 \\
6-11 Bulan & 14,7 & 19,1 & 33,8 & 66,2 \\
12-23 Bulan & 14,9 & 20,2 & 35,1 & 64,9 \\
24-35 Bulan & 13,2 & 19,3 & 32,5 & 67,5 \\
36-47 Bulan & 13,3 & 19,2 & 32,5 & 67,5 \\
48-60 Bulan & 12,7 & 19,6 & 32,2 & 67,8 \\
\hline Jumlah & 13,9 & 19,6 & 33,5 & 66,5 \\
\hline
\end{tabular}




\section{BAHASAN}

Memperhatikan hasil analisis di atas dapat diartikan bahwa kita tidak boleh lengah terhadap anak yang saat ini dikategorikan berstatus gizi baik (normal) karena sebagian dari mereka memiliki posisi yang rawan untuk jatuh ke status yang lebih buruk. Mengingat jumlah anak balita berstatus gizi baik (normal) yang ada pada posisi rawan terus meningkat mengikuti pertambahan usia, maka upaya perbaikan gizi yang bersifat preventif sudah harus dilaksanakan sejak usia dini, tidak hanya untuk anak balita kurang gizi tetapi juga bagi anak balita yang dikategorikan berstatus gizi baik.

Upaya yang bersifat preventif ini sangat penting mengingat tingginya risiko yang dihadapi anak yang kurang gizi (BB rendah, pendek, kurus) untuk jatuh ke keadaan yang lebih buruk (BB sangat rendah, sangat pendek, sangat kurus). Ini berarti bahwa sekali anak yang berstatus gizi normal jatuh menjadi kurang gizi, maka probabilitas anak tersebut menjadi tinggi untuk jatuh ke status gizi yang buruk.

Seperti air terjun yang terus mengalir, kejadian kasus gizi buruk akan selalu ada apabila perhatian terhadap penganggulangan gizi buruk terfokus hanya pada penanganan penderita gizi buruk. Mencegah anak yang berstatus gizi baik (normal) agar tidak jatuh ke keadaan yang lebih buruk, dan menangani anak yang berstatus gizi kurang agar tidak jatuh menjadi buruk merupakan upaya yang juga sudah harus mendapatkan prioritas perhatian di samping upaya penanganan kasus gizi buruk itu sendiri. Keadaan tersebut dapat lebih buruk pada keadaan lingkungan yang kurang sehat dan keadaan sosial ekonomi keluarga yang kurang menguntungkan.

Upaya pencegahan tidak lepas dari upaya peningkatan kinerja Posyandu sebagai ujung tombak upaya perbaikan gizi di masyarakat, dan juga tidak lepas dari peningkatan kinerja Sistem Kewaspadaan Pangan dan Gizi (SKPG). Revitalisasi posyandu dan SKPG yang sudah dilakukan beberapa tahun terakhir belum menampakkan hasil yang menggembirakan. Upaya-upaya perbaikan gizi masyarakat melalui berbagai program tanpa ditunjang oleh kinerja posyandu dan SKPG yang baik akan menghasilkan keadaan seperti sekarang ini di mana prevalensi anak balita gizi kurang (BB/U rendah) tidak banyak mengalami penurunan selama sewindu terakhir, dan masih seringnya ditemukan balita gizi buruk.

Arah kebijakan pemerintah untuk meningkatkan upaya perbaikan gizi secara umum dan penanggulangan gizi buruk, khususnya melalui peningkatan kegiatan yang bersifat PREVENTIF dan PROMOTIF yang PROAKTIF, harus diimplementasikan secara benar, baik di pusat maupun di daerah.

\section{SIMPULAN}

1. Anak balita yang saat ini berstatus gizi baik (BB/U normal, TB/U Normal, BB/TB Normal) masih memiliki peluang untuk jatuh ke keadaan kurang gizi (BB/U rendah, TB/U pendek, BB/TB kurus). Peluang ini semakin tinggi seiring dengan pertambahan usia anak.

2. Anak balita yang saat ini berstatus kurang gizi (BB/U rendah, TB/U pendek, BB/TB kurus) memiliki peluang yang tinggi untuk jatuh ke keadaan yang lebih buruk (BB/U sangat rendah, TB/U sangat pendek, $\mathrm{BB} / \mathrm{TB}$ sangat kurus). Peluang ini hampir sama tinggi untuk setiap umur.

\section{REKOMENDASI}

1. Mengingat hal tersebut, maka upaya yang bersifat preventif dan promotif sudah harus mendapatkan prioritas perhatian dalam implementasinya.

2. Untuk upaya yang bersifat preventif dan promotif, peningkatan kinerja pemantauan pertumbuhan di posyandu dan kinerja SKPG perlu digalakkan dan dijalankan dengan benar.

\section{RUJUKAN}

1. Sekretariat Negara. Inpres No. 8, tahun 1998 tentang Gerakan Penanggulangan Masalah Pangan dan Gizi. Jakarta, Indonesia.

2. Departemen Dalam Negeri. Surat Edaran Menteri Dalam Negeri No. 411.3/536/SJ/1999 tentang Revitalisasi Posyandu. Jakarta, Indonesia. 
3. Departemen Dalam Negeri. Surat Edaran Menteri Dalam Negeri No. 411.3/1116/SJ/1999 tentang Pedoman Umum Revitalisasi Posyandu. Jakarta, Indonesia

4. Azwar, Azrul. Arah perbaikan kesehatan dan gizi tahun 2010. Makalah disampaikan pada Workshop Perbaikan Kesehatan dan Gizi Keluarga di Posyandu, 28-30 September 2003. Bandung.

5. Departemen Kesehatan RI. Profil Kesehatan 2001. Jakarta: Depkes RI.

6. Jahari AB. Pemahaman Peran Sistem Kewaspadaan Pangan dan Gizi (SKPG) dalam Pemantauan, Analisis Pemetaan dan Peramalan Situasi Pangan dan Gizi. Makalah disampaikan pada Pelatihan Pemanatauan SKPG, 2004. Bogor, Indonesia
7. Jahari $A B$. Pemantauan Pertumbuhan dalam Sistem Kewaspadaan Dini (Surveilans Gizi). Makalah disampaikan pada Pelatihan Pemantauan Pertumbuhan Balita,2005. Bogor, Indonesia.

8. Martianto D. Penguatan SKPG dalam proses pengambilan keputusan untuk perbaikan pangan dan gizi masyarakat. Makalah disampaikan pada Pra Widyakarya Nasional Pangan dan Gizi; 2008. Jakarta, Indonesia.

9. World Health Organization. WHO Child Growth Standard: Technical Report on Method and Development Length/heightfor-age, weight-for-age, weight-forlength,weight-for-height and body mass index-for-age. Geneva: WHO, 2006.

10. WHO. Anthropometry 2005: Software for assessing growth and development of the world's children. Geneva: WHO, 2005. 